\title{
Retraction Note: Behavior Analysis on the Security Object of the Public Re- ntal Housing
}

\author{
Yanhai Zhang* and Yaoiwu Wang \\ School of Management, Harbin Institute of Technology, Harbin, 150001, China
}

\section{RETRACTION}

The Publisher and Editor have retracted this article [1] in accordance with good ethical practices. After a thorough investigations we believe that the peer review process was compromised. The article was published on-line on प०-प०-2015.

\section{REFERENCE}

[1] Y. Zhang and Y. Wang, "Behavior analysis on the security object of the public rental housing”, The Open Construction and Building

Technology Journal, vol. 9, pp. 233-237, 2015.

(C) Zhang and Wang; Licensee Bentham Open.

This is an open access article licensed under the terms of the Creative Commons Attribution-Non-Commercial 4.0 International Public License (CCBY-NC 4.0) (https://creativecommons.org/licenses/by-nc/4.0/legalcode), which permits unrestricted, non-commercial use, distribution and reproduction in any medium, provided the work is properly cited. 